\title{
PERBANDINGAN MOTIVASI BELAJAR ANTARA SISWA JURUSAN IPA DAN JURUSAN IPS DI SMA NEGERI ANGGABERI KABUPATEN KONAWE
}

\author{
oleh: \\ DODI PRIYATMO SILONDAE \\ Dosen Jurusan Bimbingan dan Konseling, Fakultas Keguruan dan Ilmu Pendidikan \\ Universitas Halu Oleo \\ Email: dodi_silondae@uho.ac.id
}

\begin{abstract}
ABSTRAK
Tujuan penelitian ini untuk mengetahui perbedaan motivasi belajar antara siswa jurusan IPA dan jurusan IPS di SMA Negeri Anggaberi tahun ajaran 2010/ 2011. Populasi penelitian ini adalah seluruh siswa kelas XI dan XII SMA Negeri Anggaberi tahun pelajaran 2010/ 2011 sebanyak 174 orang yang tersebar pada 6 kelas. Pengambilan sampel menggunakan teknik proportional random sampling sejumlah $25 \%$ atau sebanyak 46 siswa. Hipotesis penelitian adalah terdapat perbedaan motivasi belajar antara siswa jurusan IPA dan jurusan IPS di SMA Negeri Anggaberi tahun ajaran 2010/ 2011. Pengumpulan data dilakukan menggunakan angket. Data dianalisis menggunakan analisis statistik deskriptif dan statistik inferensial. Hasil analisis deskriptif menunjukkan perolehan nilai rata-rata motivasi belajar untuk siswa jurusan IPA adalah 123,78 dan untuk siswa jurusan IPS adalah 120,21. Hasil analisis inferensial menunjukkan perolehan nilai $t_{\text {hitung }}(4,37)$ lebih besar dibanding $t_{\text {tabel }}(1,68)$ sehingga dapat disimpulkan bahwa hipotesis diterima yang berarti terdapat perbedaan motivasi belajar antara siswa jurusan IPA dan jurusan IPS.
\end{abstract}

\section{Kata Kunci: Motivasi Belajar Siswa, Jurusan IPA, Jurusan IPS}

\section{PENDAHULUAN}

Pembangunan nasional bertujuan mewujudkan masyarakat Indonesia yang damai, berkeadilan, berdaya saing maju dan sejahtera dalam wadah Negara Kesatuan Republik Indonesia yang didukung oleh manusia Indonesia yang sehat, mandiri, beriman, bertakwa, berahlak mulia, cinta tanah air, berkesadaran hukum dan lingkungan, menguasai ilmu pengetahuan dan teknologi, memiliki etos kerja yang tinggi dan berdisiplin. Hal ini merupakan visi reformasi pembangunan nasional Indonesia yang merupakan amanat undang-undang dasar tahun 1945.
Mewujudkan manusia Indonesia yang berkualitas merupakan tanggung jawab seluruh komponen bangsa Indonesia khususnya yang bergelut di bidang pendidikan. Pendidikan mempunyai peran amat menentukan, tidak hanya bagi perkembangan dan perwujudan diri individu tetapi juga bagi pembangunan suatu bangsa dan negara. Kemajuan suatu kebudayaan tergantung dari bagaimana kebudayaan tersebut mengenali, menghargai, dan memanfaatkan sumber daya manusianya. Hal ini berkaitan erat dengan kualitas pendidikan yang diberikan kepada anggota-anggota masyarakat. 
Berdasarkan jalurnya, pendidikan dibagi atas tiga jenis yaitu pendidikan informal, pendidikan formal dan pendidikan non formal. Pendidikan informal didapatkan dalam lingkungan keluarga yang diberikan oleh anggota keluarga berupa nilai-nilai, normanorma, kebiasaan, pola tingkah laku yang kesemuanya diberikan melalui komunikasi verbal dan non verbal serta keteladanan. Pendidikan Formal berupa pendidikan yang mempunyai jenjang dan tingkatan tertentu, dimulai dari pendidikan dasar, pendidikan menengah dan pendidikan tinggi. Sedangkan pendidikan non formal pendidikan yang diperoleh dari lingkungan tempat manusia hidup dan beradaptasi.

Dalam undang-undang nomor 20 tahun 2003 Pasal 18 tentang sistem pendidikan nasional disebutkan bahwa pendidikan menengah berbentuk Sekolah Menengah Atas (SMA, Madrasah Aliyah, SMK dan Madrasah Aliyah Kejuruan, dan bentuk lainnya yang sederajat) sehingga konsekuensi dari munculnya perundang-undangan tersebut adalah kembalinya nama SMA yang sebelumnya bernama SMU.

Pada jenjang SMA, siswa dikelompokkan berdasarkan beberapa jurusan yang antara lain ialah IPA, IPS dan Bahasa dengan maksud agar siswa lebih siap dalam memutuskan jurusan/ keahlian yang akan digeluti jika nantinya melanjutkan ke pergururan tinggi serta agar lulusan tersebut memiliki keahlian yang spesifik sebagai modal yang dapat di aplikasikan pada dunia kerja. Berdasarkan dua hal tersebut, proses penjurusan ini begitu penting artinya bagi siswa dalam rangka merencanakan karirnya dimasa yang akan datang.
Gani (1986:14) mengemukakan bahwa penjurusan merupakan suatu proses penempatan dalam pemilihan program studi pasa siswa yang bertujuan:

1. Mengelompokkan siswa yang memiliki kecakapan, kemampuan, bakat dan minat yang sama.

2. Membantu mempersiapkan dalam melanjutkan studi dan memilih kerjanya.

3. Membantu memperkokoh keberhasilan dan prestasi yang dicapai pada waktu mendatang.

4. Membantu meramalkan keberhasilan untuk mencapai prestasi yang baik dalam kelanjutan studi dan dunia kerja

Terlepas dari jurusan apapun yang dipilih oleh para siswa, mereka harus mampu menunjukkan prestasi belajar yang optimal. Melalui pencapaian prestasi yang optimal, siswa akan mencapai tingkat produktifitas sebagaimana potensi yang dimilikinya. Pencapaian prestasi siswa yang gemilang tersebut, tentu tidak hanya bisa dikukur dengan deretan skor/ nilai mata pelajaran yang tinggi/ baik namun juga harus selaras dengan kepribadian serta akhlak yang mulia.

Prestasi belajar yang diraih oleh seluruh siswa haruslah merata, hal ini akan mampu mewujudkan tujuan pendidikan nasional Negara Kesatuan Republik Indonesia. Akan tetapi, pemerataan pencapaian prestasi belajar masih menjadi salah satu masalah yang terjadi di Indonesia.

Ketidakmerataan pencapaian prestasi belajar dipengaruhi oleh banyak hal, perbedaan pengalaman belajar, keberadaan dan kualitas tenaga pengajar, ketersediaan sumber, materi dan media belajar, keterbatasan sarana 
dan sarana pendidikan serta berbagai hal yang berasal dari dalam diri peserta didik, apakah yang sifatnya lahiriah ataupun yang sifatnya bathiniah.

Persoalan tidak meratanya prestasi belajar siswa, juga terjadi di SMA Negeri Anggaberi. Berdasarkan hasil pra penelitian di sekolah tersebut pada tanggal 17 Mei 2010 diperoleh informasi bahwa siswa jurusan IPA selalu meraih juara umum sejak tahun 2005 sampai tahun 2010. Selain itu, informasi yang dikumpulkan juga menunjukkan fakta bahwa nilai ratarata siswa jurusan IPA selalu lebih tinggi daripada nilai rata-rata jurusan IPS.

Fenomena kesenjangan prestasi belajar antara kedua jurusan tersebut dapat dipengaruhi oleh berbagai faktor, baik yang bersumber dari dalam diri siswa (internal) maupun yang bersumber dari luar diri siswa (eksternal). Salah satu faktor yang dapat menyebabkan perbedaan prestasi belajar adalah motivasi belajar siswa. Motivasi belajar dapat diartikan sebagai suatu bagian dalam diri siswa yang dapat menyebabkan siswa tersebut mau dan mampu melakukan kegiatan belajar dengan cara tertentu.

$\begin{array}{rcr}\text { Motivasi } & \text { belajar siswa dapat } \\ \text { mempengaruhi } & \text { prestasi } & \text { yang }\end{array}$ dicapainya dikarenakan untuk dapat mencapai hasil belajar yang optimal, siswa dituntut untuk mampu bekerja secara keras dan secara cerdas dalam setiap aktfitasnya, dan untuk memiliki kedua kemampuan tersebut siswa harus memiliki motivasi belajar yang tinggi. Motivasi belajar penting bagi siswa dalam mengikuti proses pembelajaran, karena motivasi belajar tersebutlah yang akan menggerakkan siswa dalam memilih tindakan dan tujuan belajar yang dirasa paling berguna bagi kehidupan siswa.

Berangkat dari fenomena prestasi belajar siswa di SMA Negeri Anggaberi serta keterkaitan yang erat antara prestasi belajar yang dimiliki oleh seorang siswa motivasi belajar yang dimilikinya, peneliti bermaksud untuk melakukan penelitian yang membandingkan tingkat motivasi belajar antara siswa Jurusan IPA dan Jurusan IPS, sehingga penelitian ini berjudul "Perbandingan Motivasi Belajar Antara Siswa Jurusan IPA dan Jurusan IPS di SMA Negeri Anggaberi Tahun Pelajaran 2010/ 2011."

Tujuan yang ingin di capai dalam penelitian ini adalah untuk mengetahui perbedaan motivasi belajar antara siswa jurusan IPA dengan siswa jurusan IPS di SMA Negeri Anggaberi tahun ajaran 2010/ 2011.

\section{Pengertian Motivasi Belajar}

Winkel (2005: 160) menyebutkan motivasi belajar adalah keseluruhan daya penggerak psikis di dalam siswa yang menimbulkan kegiatan belajar itu demi mencapai suatu tujuan. Senada dengan Winkel, Uno (2011: 23) menyatakan bahwa motivasi belajar adalah dorongan internal dan eksternal pada siswa yang sedang belajar untuk mengadakan sebuah tingkah laku belajar.

Berdasarkan dua pendapa ahli tersebut, dapat ditarik sebuah kesimpulan bahwa segala hal yang dapat mendorong seorang siswa untuk melakukan aktifitas belajar baik yang berasal dari dalam diri ataupun luar diri siswa tersebut. 


\section{Jenis Motivasi Belajar}

Menurut Syah (2003:151) motivasi dapat di bedakan menjadi dua macam, yakni:

1. Motivasi intrinsik, adalah hal dan keadaan yang berasal dari dalam diri individu yang dapat mendorongnya melakukan suatu tindakan. Termasuk dalam motivasi intrinsik adalah perasaan menyenangi materi dan kebutuhannya terhadap materi tersebut, misalnya untuk kehidupan masa depan orang yang bersangkutan.

2. Motivasi ekstrinsik, adalah hal dan keadaan yang berasal dari luar individu yang juga mendorongnya melakukan suatu tindakan. Pujian dan hadiah, peraturan/ tata tertib, suri tauladan dan seterusnya adalah contoh-contoh konkret motivasi ekstrinsik.

\section{Ciri-ciri Motivasi Belajar}

Motivasi belajar yang ada pada siswa menimbulkan kegiatan untuk belajar. Untuk mengetahui apakah seseorang mempunyai motivasi terhadap kegiatan tertentu, maka ada ciri-ciri yang nampak pada orang tersebut. Menurut Sardiman (2006:82) ciri-ciri yang nampak pada orang yang mempunyai motivasi adalah sebagai berikut : 1) tekun menghadapi tugas. 2) ulet menghadapi kesulitan, 3) menunjukkan minat terhadap macammacam masalah, 4) lebih senang bekerja sendiri, 5) cepat bosan terhadap hal-hal yang rutin (hal-hal yang bersifat mekanis, berulang-ulang begitu saja sehingga kurang kreatif), 6) dapat mempertahankan pendapat, 7) tidak mudah melepaskan hal-hal yang diyakininya dan 8) senang mencari dan memecahkan masalah dari soal-soal.

\section{Karakteristik jurusan IPA}

Kurikulum pendidikan ilmu pengetahuan alam (IPA) yang disiapkan adalah agar peserta didik memiliki kemampuan untuk melanjutkan dan memperluas wawasan tentang IPA yang di peroleh pada pendidikan dasar sebagai bekal untuk melanjutkan ke pendidikan tinggi.

Nur (1987: 21) menjelaskan bahwa tujuan pendidikan IPA adalah agar siswa memahami konsep IPA dan keterkaitannya, serta mampu menggunakan metode ilmiah untuk memecahkan masalah yang dihadapinya, sehingga lebih menyadari kebebasan dan kekuasaan penciptanya. Oleh karena itu pendidikan IPA juga mengembangkan sikap, nilai dan keterampilan sesuai dengan tingkat dan kemampuan peserta didik pada pendidikan menengah, antara lain:

1. Rasa cinta pada alam lingkungan

2. Kesadaran akan pentingnya pengembangan dan pemanfaatan sumber daya alam serta menjaga kelestariannya.

3. Keterampilan untuk memperoleh, mengembangkan dan menerapkan konsep-konsep biologi, fisika dan keterkaitannya

4. Keterampilan untuk mengadaptasikan diri dalam lingkungan sosial

5. Menentukan sikap ilmiah kepada siswa dan melatih siswa untuk memecahkan masalah yang dihadapi secara ilmiah

Selanjutnya, Soejanto (dalam Amir, 1999: 11) mengemukakan prinsip-prinsip belajar IPA sebagai berikut: 1) belajar harus dengan terencana dan teratur, 2) belajar harus dengan berdisiplin diri, 3) belajar harus 
dengan minat/perhatian, 4) belajar harus dengan perhatian, 5) belajar harus dengan tujuan yang jelas dan 6) belajar harus diselingi dengan rekreasi sederhana yang bermanfaat.

\section{Karakteristik jurusan IPS}

Pendidikan ilmu pengetahuan sosial (IPS) pada hakikatnya merupakan bidang yang mempelajari kehidupan sosial di dalam suatu masyarakat. Bidang kajian ini bertumpu pada kajian tentang manusia dan masyarakat.

Sumantri (1996: 4) ruang lingkup pengembangan Ilmu Pengetahuan Sosial (IPS) di bagi dalam tiga sub tujuan, yaitu: 1) IPS sebagai pendekatan kewarganegaraan, 2) IPS sebagai ilmu konsep dan generalisasinya dalam disiplin dan ilmu-ilmu sosial dan 3) IPS sebagai ilmu yang menyerap ilmu pendidikan dari kehidupan nyata dalam masyarakat kemudian dikaji secara reflektif. Sedangkan Hasan (1989) mengungkapkan uraian materi IPS dilakukan dengan menggunakan dua pendekatan, yaitu pendekatan logis dan pendekatan pedagogis.

Setiap mata pelajaran memiliki karakteristik tersendiri yang berbeda dengan mata pelajaran lainnya, tidak terkecuali dengan mata pelajaran di jurusan IPS yang memiliki sejumlah karakteristik tertentu, yakni sebagai berikut:

1. Ilmu Pengetahuan Sosial (IPS) merupakan perpaduan dari berbagai disiplin ilmu sosial antara lain: sosiologi, geografi, ekonomi, dan sejarah

2. Materi pelajaran Ilmu Pengetahuan Sosial (IPS) terdiri atas konsep, prinsip, dan tema yang berkenaan dengan hakikat kehidupan manusia sebagai makhluk sosial
3. Kajian Ilmu Pengetahuan Sosial (IPS) di kembangkan melalui tiga pendekatan utama, yaitu functional approach, interdicipliner approach dan multidicipliner approach.

4. Materi Ilmu Pengetahuan Sosial (IPS) senantiasa berkenaan dengan fenomena dinamika sosial, budaya dan ekonomi yang menjadi bagian integral dalam kehidupan masyarakat dari waktu ke waktu dan dari tempat ke tempat baik dalam skala kelompok masyarakat, lokal, nasional, regional, dan global

\section{METODE PENELITIAN}

\section{Lokasi dan Waktu Penelitian}

Penelitian ini dilaksanakan di SMA Negeri Anggaberi pada tahun ajaran 2010/ 2011.

\section{Jenis Penelitian}

Penelitian ini merupakan penelitian komparatif, yaitu penelitian yang bertujuan untuk mengetahui perbedaan dari dua variabel yang diteliti untuk memperoleh suatu kesimpulan (Arikunto, 2010: 247).

\section{Populasi dan Sampel}

1. Populasi

Populasi dalam penelitian ini adalah seluruh siswa kelas XI dan XII (Jurusan IPA dan IPS) SMA Negeri Anggaberi tahun pelajaran 2010/ 2011 yang berjumlah 174 orang.

2. Sampel

Pengambilan sampel dilakukan dengan teknik proporsional random sampling. Hal ini dilakukan dengan mengacu pada pendapat Arikunto 
(2010: 8) yang menyatakan bahwa jika jumlah populasi lebih dari 100 orang maka pengambilan sampel sebaiknya berkisar antara $15 \%$ $25 \%$. Berhubung jumlah responden lebih dari 100 orang maka sampel yang diambil sebanyak $25 \%$ untuk tiap kelas, sehingga jumlah sampel penelitian sebanyak 46 siswa. adapun rincian Populasi dan sampel dapat dilihat pada tabel berikut.

Tabel 1. Rincian Populasi dan Sampel Penelitian

\begin{tabular}{cccc}
\hline No & Kelas & $\sum$ Siswa & Sampel \\
\hline 1 & XII IPA & 31 & 8 \\
\hline 2 & XI IPA.1 & 26 & 7 \\
\hline 3 & XI IPA.2 & 29 & 8 \\
\hline 4 & XII IPS & 31 & 8 \\
\hline 5 & XI IPS.1 & 27 & 7 \\
\hline 6 & XI IPS.2 & 30 & 8 \\
\hline \multicolumn{2}{c}{ Jumlah } & $\mathbf{1 7 4}$ & $\mathbf{4 6}$ \\
\hline
\end{tabular}

\section{Instrumen Penelitian}

Instrumen yang digunakan dalam penelitian ini adalah Angket yang disusun dengan menggunakan skala Likert. Angket disusun peneliti dengan mengembangkan indikator motivasi belajar dengan menawarkan 5 pilihan jawaban yakni Sangat Sesuai (SS), Sesuai (S), Netral (N), Tidak Sesuai (TS) dan Sangat Tidak Sesuai (STS).

\section{Teknik Analisis Data}

Data yang telah diperoleh dari hasil penelitian kemudian dianalisis secara deskriptif dan inferensial.

1. Analisis deskriptif

Analisis deskriptif digunakan untuk mendeskripsikan karakteristik distribusi skor responden masing- masing variabel dengan langkah: a) mentabulasi data penelitian, b) menentukan nilai maksimum, nilai minimum, nilai rata-rata, dan standar deviasi (SD) dan c) membuat tabel distribusi frekuensi

2. Analisis inferensial

Analisis inferensial digunakan untuk pengujian hipotesis penelitian dengan menggunakan uji-t dari dua sampel yang terpisah. Adapun langkah-langkah pengujian diuraikan sebagai berikut: a) melakukan uji normalitas data, b) melakukan uji homogenitas varians dan c) uji-t

\section{HASIL DAN PEMBAHASAN}

\section{Hasil Penelitian}

\section{Analisis data deskriptif}

1. Motivasi belajar siswa jurusan IPA Data mengenai gambaran motivasi belajar siswa jurusan IPA di SMA Negeri Anggaberi dapat dilihat melalui tabel berikut ini:

Tabel 2. Motivasi Belajar Siswa Jurusan IPA

\begin{tabular}{cccc}
\hline Sampel & Skor & Sampel & Skor \\
\cline { 2 - 3 } & $\mathbf{X}_{\mathbf{1}}$ & & $\mathbf{X}_{\mathbf{1}}$ \\
\hline 1 & 122 & 13 & 125 \\
\hline 2 & 126 & 14 & 123 \\
\hline 3 & 123 & 15 & 120 \\
\hline 4 & 122 & 16 & 125 \\
\hline 5 & 124 & 17 & 123 \\
\hline 6 & 125 & 18 & 124 \\
\hline 7 & 126 & 19 & 125 \\
\hline 8 & 120 & 20 & 125 \\
\hline 9 & 126 & 21 & 123 \\
\hline 10 & 125 & 22 & 124 \\
\hline 11 & 124 & 23 & 123 \\
\hline 12 & 124 & & \\
\hline \multicolumn{5}{c}{ Skor rata-rata } \\
\hline
\end{tabular}


Berdasarkan data pada tabel tersebut, terlihat bahwa skor rata-rata 123,78 dengan skor minimum yang diperoleh adalah 120 dan skor maksimum adalah 126.

2. Motivasi belajar siswa jurusan IPS Data mengenai gambaran motivasi belajar siswa jurusan IPS di SMA Negeri Anggaberi dapat dilihat melalui tabel berikut ini:

Tabel 3. Gambaran Motivasi Belajar Siswa Jurusan IPS

\begin{tabular}{cccc}
\hline Sampel & Skor & Sampel & Skor \\
\cline { 2 - 3 } & $\mathbf{X}_{\mathbf{2}}$ & & $\mathbf{X}_{\mathbf{2}}$ \\
\hline 1 & 122 & 13 & 118 \\
\hline 2 & 123 & 14 & 120 \\
\hline 3 & 120 & 15 & 121 \\
\hline 4 & 119 & 16 & 119 \\
\hline 5 & 121 & 17 & 118 \\
\hline 6 & 122 & 18 & 120 \\
\hline 7 & 119 & 19 & 119 \\
\hline 8 & 120 & 20 & 120 \\
\hline 9 & 119 & 21 & 117 \\
\hline 10 & 121 & 22 & 121 \\
\hline 11 & 123 & 23 & 120 \\
\hline 12 & 123 & \\
\hline \multicolumn{5}{c}{ Skor rata-rata } \\
\hline
\end{tabular}

Berdasarkan data pada tabel tersebut, terlihat bahwa skor rata-rata 120,21 dengan skor minimum yang diperoleh adalah 117 dan skor maksimum adalah 123 .

\section{Analisis data inferensial}

Sebelum dilakukan analisis statistik, data skor motivasi belajar siswa diuji normalitas distribusinya dan homogenitasnya terlebuh dahulu menggunakan uji chi-kuadrat $\left(\chi^{2}\right)$ dan uji-F. hasil analisis menunjukkan kedua data kelompok tersebut memiliki distribusi normal dan homogen.

Setelah mengetahui bahwa kedua data kelompok tersebut berdistribusi normal dan homogen, langkah selanjutnya adalah melakukan uji-t untuk dua sample bebas. Berdasarkan hasil analisis data statistik dengan menggunakan bantuan program SPSS 16.00 maka diperoleh data sebagaimana yang tersaji pada tabel berikut:

Tabel 4. Hasil Analisis Uji-t

\begin{tabular}{|c|c|c|c|c|c|}
\hline \multicolumn{6}{|c|}{ Group Statistics } \\
\hline & KELOMPOK & $\mathrm{N}$ & Mean & $\begin{array}{c}\text { Std. } \\
\text { Deviation }\end{array}$ & $\begin{array}{l}\text { Std. Error } \\
\text { Mean }\end{array}$ \\
\hline NILAI J & JURUSAN IPA & 23.00 & 123.78 & 1.68 & 0.35 \\
\hline & JURUSAN IPS & 23.00 & 120.22 & 1.65 & 0.34 \\
\hline
\end{tabular}

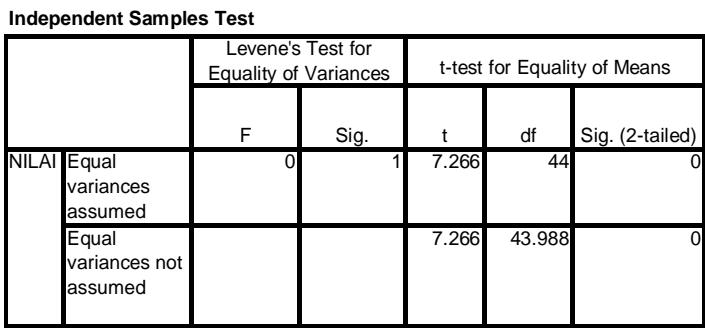

Berdasarkan output yang disajikan pada tabel tersebut, terlihat bahwa nilai sig-(2 tailed) sebesar o,oo yang lebih kecil jika dibandingkan dengan 0,05, sehingga dapat ditarik kesimpulan bahwa terdapat perbedaan yang signifikan antara rata-rata skor motivasi belajar siswa jurusan IPA dengan motivasi belajar siswa jurusan IPS di SMA Negeri Anggaberi.

\section{Pembahasan}

Hasil penelitian menunjukkan bahwa di SMA Negeri Anggaberi tahun ajaran 2010/ 2011, tingkat motivasi belajar siswa jurusan IPA lebih tinggi jika dibandingkan dengan tingkat motivasi belajar siswa jurusan IPS. Hal ini menunjukkan bahwa fenomena tingginya nilai rata-rata mata pelajaran siswa jurusan IPA dibandingkan jurusan IPS sejalan dengan tingkat motivasi 
belajar yang dimiliki oleh siswa pada jurusan tersebut.

Hasil penelitian ini juga sejalan dengan hasil penelitian yang dilakukan oleh Pusparia (2008) yang berjudul "Perbedaan Motivasi Berprestasi pada Siswa SMA Berdasarkan Penjurusan Program studi IPA, IPS dan Bahasa". Hasil penelitian menunjukkan bahwa berdasarkan penjurusan, motivasi berprestasi siswa jurusan IPA cenderung lebih tinggi daripada siswa jurusan IPS, dan Bahasa.

Motivasi belajar merupakan faktor psikis yang bersifat non-intelektual. Peran motivasi belajar yang khas adalah dalam hal penumbuhan semangat/ gairah dan perasaan senang untuk menjalani aktifitas belajar. Siswa yang memiliki motivasi belajar yang kuat umumnya memiliki banyak energi untuk melakukan kegiatan belajar dibandingkan dengan yang motivasi belajarnya rendah. Memiliki motivasi yang tinggi kedepannya akan meneguhkan minat siswa serta menyempurnakan bakat yang ada di dalam dirinya. Dengan demikan, diharapkan siswa dapat memilih berbagai hal dalam kehidupan akademik maupun kehidupan sosialnya secara tepat.

Motivasi belajar yang tinggi hendaknya berada pada semua siswa di sekolah, tidak peduli dengan latar belakang sosial dan ekonominya, maupun dengan jurusan/ peminatan yang dipilihnya. Penjurusan pada Sekolah Menenag Atas (SMA) sejatinya karena kesadaran akan pentingnya perbedaan individual pada semua siswa sehingga karena perbedaan tersebut, mereka memerlukan wadah yang dapat mendukungnya dalam menjalani kegiatan pendidikan di sekolah sebagaimana kondisi dirinya.

Selain karena adanya perbedaan individual, pengelompokan siswa ke dalam beberapa jurusan di SMA memiliki beberapa tujuan antara lain:

1. Untuk membantu siswa dalam studi lanjutnya ke perguruan tinggi dan/ atau memilih dunia kerja yang sesuai keadaan dirinya, serta

2. Untuk membantu siswa memantapkan peluang keberhasilan yang akan dicapainya pada masa yang akan datang.

Persoalan rendahnya motivasi belajar pada jurusan IPS di SMA Negeri 1 Anggaberi pada tahun ajaran 2010/ 2011 perlu mendapatkan perhatian khusus bagi seluruh personil pendidikan di sekolah tersebut, hal ini perlu dilakukan untuk mematahkan stigma yang telah ada sejak dahulu bahwa memang jurusan IPA selalu selbih superior dibandingkan juusan IPS, jurusan IPS hanyalah "kelas dua" dalam strata sosial di sekolah hingga jurusan IPS sebagai sarang dari kumpulan siswa yang kurang pandai dan malas belajar.

Selain itu, jika persoalan rendahnya motivasi belajar ini berlangsung secara terus menerus dan dalam jangka waktu yang cukup lama, tidak hanya sekolah yang akan menanggung akibat ketika pelaksanan ujian nasioan, tapi jauh lebih besar daripada itu, masa depan mereka sebagai individu serta masa depan daerah dan negara yang akan menjadi taruhannya, karena sejatinya di masa depan para siswa tersebutlah yang akan menjadi aktor utama pembangunan nasional di negara ini. 


\section{KESIMPULAN DAN SARAN}

\section{Kesimpulan}

Berdasarkan hasil uji analisis statistik menggunakan uji-t, terlihat bahwa nilai sig-(2 tailed) sebesar o,oo yang lebih kecil jika dibandingkan dengan 0,05, sehingga dapat ditarik kesimpulan bahwa terdapat perbedaan yang signifikan antara rata-rata skor motivasi belajar siswa jurusan IPA dengan motivasi belajar siswa jurusan IPS di SMA Negeri Anggaberi pada tahun ajaran 2010/ 2011.

\section{Saran}

Berdasarkan hasil penelitian dan kesimpulan yang telah diuraikan, peneliti mengemukakan beberapa saran sebagai berikut:

1. Kepada siswa, hendaknya senantiasa menumbuhkan motivasi di dalam dirinya (motivasi intrinsik) sehingga dapat meningkatkan prestasi belajar yang di perolehnya.

2. Kepada guru mata pelajaran terkhusus pada Jurusan IPS, hendaknya dalam melakukan proses pembelajaran selalu menyempatkan diri untuk meningkatkan motivasi belajar siswa sebab dengan motivasi belajar yang tinggi.

3. Kepada wali kelas, hendaknya senantiasa memotivasi anak perwaliannya yang mengalami penurunan prestasi belajar.

4. Kepada kepala sekolah, hendaknya selalu memberikan pengarahan kepada seluruh personil yang ada di dalam sekolah bahwa jurusan IPA dan jurusan IPS memiliki karakteristik masing-masing, bukan sebagai media dikotomi kecerdasan siswa.

\section{DAFTAR PUSTAKA}

Amir, M. 1999. Prinsip-prinsip Belajar Siswa. Jakarta: Bina Aksara.

Arikunto, Suharsimi. 2010. Prosedur Penelitian Suatu Pendekatan Praktik. Jakarta: Rineka Cipta.

Gani. Ruslan Abdul, 1986. Bimbingan Penjurusan. Bandung : PT. Angkasa.

Hasan, Hamid.1989.Model-model Mengajar Ilmu Pengetahuan Sosial. Bandung: Alfa Beta.

Nur, Muhammad. 1987. Keterampilan Proses Belajar IPA dan Hakekat Pelajaran. Dirjen Dikdasmen, Jakarta.

Sardiman, 2006. Interaksi dan Motivasi Belajar Mengajar. Jakarta: PT Raja Grafindo Persada.

Sumantri. 1996. Pembinaan Guru di Indonesia. Jakarta: Dunia Pustaka Jaya.

Syah, Muhibbin. 2003. Psikologi Belajar. Jakarta: PT Raja Grafika Persada.

Undang-undang nomor 20 tahun 2003 tentang. Sistem Pendidikan Nasional.

Uno, Hamzah, B. 2011. Teori Motivasi dan Pengukurannya. Jakarta: PT Bumi. Aksara.

Winkel, W.S. 2005. Psikologi Pengajaran. Jakarta: Gramedia Pustaka Tama 